\title{
CORPORATE SOCIAL RESPONSIBILITY DALAM MEMINIMALKAN PRAKTIK MANAJEMEN LABA
}

\section{CORPORATE SOCIAL RESPONSIBILITY IN MINIMIZING EARNINGS MANAGEMENT PRACTICES}

\author{
Budi Gautama Siregar \\ Fakultas Ekonomi dan Bisnis Islam IAIN Padangsidimpuan \\ Jl. H.T. Rizal Nurdin Km. 4,5 Sihitang, Padangsidimpuan 22733 \\ e-mail: gautamasiregar@yahoo.com
}

Naskah diterima 19 Juni 2017, direview 03 Juli 2017, disetujui 03 Oktober 2017

\begin{abstract}
Information earnings, a key element in the financial statement, as stated in the Statement of Financial Accounting Concepts (SFAC) No. 2 is very important for those who use it because its predictive value. Earnings management can be applied in the preparation of financial statements through creative accounting practices, the choice of accounting methods, the classification of accounting systems and the timing of the transaction. Earnings management practices can also done through the election method of inventory accounting, depreciation of fixed assets, capitalization of pensions, inflation, and amortization. Corporate Social Responsibility (CSR) activities disclosed by the company will give good impact for the company itself in the long term. The higher the company implemented corporate social responsibility, the lower the activity of management to manage earnings to its interests. Due to the financial statements prepared by the management will be read and analyzed by stakeholders as a basis for decision making, management is required to prepare honest financial statements. Disclosure of corporate social responsibility that is increasingly widespread will improve the image of the company and increase of the profits to be earned by the company ultimately.
\end{abstract}

Keywords: Corporate Social Responsibility, minimize, earnings management

\begin{abstract}
Abstrak: Informasi pendapatan sebagai kunci dalam laporan keuangan, yang tercantum dalam Pernyataan Standar Akuntansi Keuangan (PSAK) No. 2 merupakan hal yang penting bagi mereka yang menggunakannya karena memiliki nilai prediktif. Manajemen laba dapat diterapkan dalam penyusunan laporan keuangan melalui praktik akuntansi kreatif, pilihan metode akuntansi, klasifikasi sistem akuntansi, dan waktu transaksi. Praktik pengelolaan laba juga dapat dilakukan melalui metode pemilihan persediaan, penyusutan aset tetap, kapitalisasi pensiun, inflasi, dan amortisasi. Kegiatan Corporate Social Responsibility (CSR) yang diungkapkan oleh perusahaan akan memberikan dampak yang baik bagi perusahaan itu sendiri dalam jangka panjang. Semakin tinggi perusahaan menerapkan tanggung jawab sosial perusahaan, maka semakin rendah aktivitas manajemen untuk mengelola pendapatan sesuai kepentingannya. Karena laporan keuangan yang disiapkan oleh manajemen akan dibaca dan dianalisis oleh para pemangku kepentingan sebagai dasar pengambilan keputusan, manajemen diwajibkan untuk menyiapkan laporan keuangan yang jujur. Pengungkapan tanggung jawab sosial perusahaan yang semakin meluas akan memperbaiki citra perusahaan dan meningkatkan profit.
\end{abstract}

Kata kunci: Tanggung jawab sosial perusahaan, meminimalkan, manajemen laba

\section{PENDAHULUAN}

$\int_{\text {satu tolak ukur kinerja perusahaan, yang }}^{\text {aba dalam proses akuntansi adalah salah }}$ secara akuntansi didefinisikan sebagai selisih dari pendapatan dan beban perusahaan (Ghozali
\& Chariri, 2007). Laba pada dasarnya adalah pengembalian atas sumber daya yang digunakan perusahaan pada proses berjalannya perusahaan. Tingkat pengembalian ini menjadi salah satu alat ukur kinerja perusahaan. Selain itu, laba dapat 
memberikan informasi untuk menduga aliran kas pembagian dividen kepada shareholder. Laba menjadi penting karena banyak pihak yang menggunakannya sebagai dasar untuk mengevaluasi kinerja perusahaan (Dechow, 1994). Laba tersebut merupakan sebuah proses dalam akuntansi yang memberikan kebebasan bagi para penyusunnya untuk memilih metode yang akan digunakan. Seorang manajer dapat menggunakan kebijakannya untuk menetapkan waktu, jumlah pendapatan dan biaya yang terjadi dalam perusahaan (Assih, 2005).

Laba menjadi pusat perhatian disebabkan karena laba tersebut mengandung informasi yang penting, di antaranya sebagai dasar dalam pengenaan pajak yang akan diterima negara, untuk menghitung dividen yang akan dibagikan kepada para pemilik, menjadi pedoman dalam penentuan kebijakan investasi, sebagai dasar dalam peramalan laba perusahaan untuk masa yang akan datang. Beranjak dari peranan pentingnya laba tersebut dalam berbagai proses pengambilan keputusan, maka hal ini mendorong manajer untuk mempengaruhi laba yang akan dilaporkan dengan berbagai motif tertentu.

Menurut Schipper (1989) manajemen laba dikaitkan dengan upaya untuk mengelola pendapatan atau keuntungan untuk kepentingankepentingan tertentu yang dilandasi oleh berbagai faktor ekonomi tertentu. Scott (2006) mendefinisikan manajemen laba sebagai berikut: manajemen laba merupakan pemilihan kebijakan akuntansi oleh manajer dari Standar Akuntansi Keuangan yang ada dan secara alamiah dapat memaksimalkan utilitas mereka dan atau nilai pasar perusahaan. Manajemen laba menurut
Mulford dan Comiskey (2002), merupakan financial numbers game (permainan angka-angka keuangan) yang dilakukan melalui creative accounting practises akibat adanya kelonggaran flexibility principles yang dikeluarkan oleh GAAP (General Accepted Accounting Principal).

Menurut Scott (2003), manajemen laba yang dipraktikkan perusahaan dapat bersifat efisien (good) maupun opportunistik (bad). Aktivitas manajemen laba yang efisien diharapkan reliabilitas dari laporan keuangan perusahaan bisa semakin meningkat sedangkan manajemen laba yang buruk merupakan kegiatan yang cenderung membuat catatan akuntansi palsu dan tidak mengungkapkan informasi yang sebenarnya. Praktik manajemen laba yang opportunistik akan mengindikasikan secara eksplisit praktik manajemen laba yang disengaja oleh manajer yang pada akhirnya membawa konsekuensi negatif atau buruk terhadap para stakeholder, karier, dan reputasi manajer yang bersangkutan. Efek dari akibat tindakan manajemen laba yang bersifat opportunistik tersebut di antaranya adalah menjadikan perusahaan kehilangan dukungan dari para stakeholder, di mana stakeholder akan memberikan respon negatif yang berupa tekanan dari investor, sanksi regulator, ditinggalkan rekan kerja, boikot dari para aktivis dan pemberitaan negatif di media massa (Prior et.al.,2008).

Respon negatif tersebut merupakan akibat dari ketidakpuasan stakeholder terhadap kinerja perusahaan yang dimanipulasi dan akan berujung pada rusaknya image atau reputasi perusahaan di pasar modal (Fomburn et.al., 2000). Oleh sebab itu manajer menggunakan suatu strategi pertahanan diri (entrenchment strategy) untuk mengantisipasi 
ketidakpuasan stakeholdernya ketika melaporkan kinerja perusahaan yang kurang memuaskan. Strategi pertahanan tersebut merupakan upaya untuk tetap mempertahankan image perusahaan dan melindungi karier manajer secara pribadi. Salah satu cara yang digunakan oleh pihak manajemen untuk mempertahankan diri adalah mengumumkan kebijakan perusahaan tentang penerapan Corporate Social Responsibility (CSR).

Pengungkapan CSR merupakan salah satu upaya yang dilakukan perusahaan untuk dapat memenuhi kepentingan stakeholders dan menjamin keberlangsungan perusahaan untuk jangka panjang. Pengungkapan CSR dapat dipandang sebagai cara untuk mempengaruhi persepsi prospek keuangan perusahaan di masa depan oleh pihak eksternal terutama stakeholder; analis saham, pelaku pasar modal, dan investor institusional (Brammer dan Pavelin, 2006).

Castelo et.al (2008) menjelaskan bahwa melalui kegiatan CSR perusahaaan dapat menghasilkan lebih banyak perlakuan yang lebih menguntungkan berkenaan dengan regulasi serta mendapatkan dukungan dari kelompok aktivis sosial, legitimasi dari komunitas industri dan pemberitaan positif dari media yang pada akhirnya reputasi perusahaan tetap terjaga dengan baik. Erica et.al (2011) perusahaan yang melakukan kegiatan CSRakan lebih cenderung untuk mengelola laba (pelaporan laba jujur dan tulus).

\section{METODE PENELITIAN}

Tulisan ini dibahas berdasarkan kajian teoritis dan kajian-kajian penelitian terdahulu kemudian dideskripsikan dalam menjelaskan fenomena dalam tulisan ini. tulisan membahas teori tentang agency theory, manajemen laba, motivasi manajemen laba, CSR, motivasi kegiatan CSR. Sedangkan hasilnya dikaji berdasarkan kajian empiris yaitu kajian-kajian penelitian tentang CSR dalam meminimalisasi praktek manajemen laba dalam perusahaan.

\section{PEMBAHASAN DAN HASIL}

\section{Teori Agency (Agency Theory)}

Teori agency mengungkapkan hubungan antara principal dengan agent, yang menjelaskan hubungan agensi muncul ketika satu orang atau lebih principal mempekerjakan orang lain (agent) untuk memberikan suatu jasa dan kemudian mendelegasikan wewenang pengambilan keputusan kepada agent tersebut (Jensen dan Meckling, 1976). Prinsipal merupakan orang yang memiliki perusahaan dan mendelegasikan kewenangan kepada agen untuk mengelola perusahaannya dengan harapan agar bertambahnya kekayaan dan kemakmuran prinsipal. Pada teori keagenan menekankan pada pemisahan fungsi antara kepemilikan perusahaan oleh investor dan pengendalian perusahaan oleh pihak manajemen.

Terjadinya konflik kepentingan antara prinsipal dan agen disebabkan karena agen bertindak tidak sesuai dengan kepentingan prinsipal sehingga memicu munculnya biaya keagenan (agency cost). Teori agensi mampu menjelaskan potensi konflik kepentingan di antara berbagai pihak yang berkepentingan. Konflik kepentingan ini terjadi karena perbedaan tujuan dari masing-masing pihak berdasarkan posisi dan 
kepentingan terhadap perusahaan. Sebagai agen, manajer bertanggungjawab secara moral untuk mengoptimalkan keuntungan para prinsipal, namun demikian manajer juga menginginkan untuk selalu memperoleh kompensasi sesuai dengan kontrak. Dengan demikian terdapat dua kepentingan yang berbeda dalam perusahaan di mana masing-masing pihak berusaha untuk mencapai tujuan masing-masing (berperilaku opportunistik).

Dalam teori keagenan juga disebabkan adanya asimetri informasi antara prinsipal dan agen yang dapat memberikan kesempatan kepada manajer untuk melakukan tindakan opportunistik mengenai kinerja ekonomi perusahaan sehingga dapat merugikan pemilik (pemegang saham). Dengan adanya masalah masalah keagenan ini, maka perusahaan harus menanggung biaya keagenan. Biaya keagenan (agency cost) merupakan biaya yang dikeluarkan oleh prinsipal untuk biaya pengawasan terhadap kinerja agen.

Berdasakan teori keagenan, perusahaan yang menghadapi biaya pengawasan dan biaya kontrak yang rendah cenderung akan melaporkan laba bersih atau dengan kata lain akan mengeluarkan biaya-biaya untuk kepentingan manajemen salah satunya biaya yang dapat meningkatkan reputasi perusahaan di mata masyarakat. Sebagai wujud pertanggungjawaban, manajer sebagai agen berusaha untuk memenuhi seluruh keinginan pihak prinsipal dengan melakukan kegiatan CSR. Kegiatan CSR merupakan sinyal yang dapat mengalihkan perhatian pemegang saham dari pengawasan manipuasi laba atau isu-isu lainnya dan sebagai hasilnya harga saham di pasar 38 || Budi Gautama Siregar modal akan meningkat seiring meningkatnya kepercayaan pemegang saham terhadap transparansi informasi yang diungkapkan oleh perusahaan.

\section{Manajemen Laba}

Manajemen laba diduga dilakukan oleh manajer dalam proses pelaporan keuangan suatu organisasi karena mereka mengharapkan suatu manfaat dari tindakan yang dilakukan, dengan mengasumsikan perilaku manajer adalah tindakan rasional dan mempunyai kewenangan dalam menentukan metode akuntasi (Gumanti, 2000). Manajemen laba dalam teori akuntansi positif adalah tidak hanya sebagai sebuah perilaku opportunistik manajemen saja, dan mencoba menjelaskan beberapa motivasi lain yang melatarbelakangi manajemen laba. Salah satunya adalah Debt/Equity Hypothesis di mana manajemen dalam menghindari rasio debt/ equity yang tinggi akan menggunakan metodemetode akuntansi yang akan mengurangi rasio tersebut. Selain itu dalam political cost hypothesis dikatakan manajemen laba bisa saja terjadi untuk mengurangi biaya-biaya politik yang dapat terjadi.

Mulford (2002) mendefinisikan manajemen laba sebagai tindakan manipulasi akuntansi dengan tujuan yang terkesan lebih baik untuk keperluan manajer atau perusahaan. Healy dan Wahlen (1999) mengatakan manajemen laba terjadi ketika manajer menggunakan pertimbangan dalam pelaporan keuangan dan penyusunan transaksi untuk merubah laporan keuangan. Schipper (1989) mendefinisikan manajemen laba sebagai suatu intervensi dengan 
maksud tertentu terhadap proses pelaporan keuangan eksternal dengan sengaja. Gumanti (2000) berpendapat bahwa manajemen laba terjadi ketika manajer, mempunyai dorongan untuk melakukan manajemen laba untuk mempengaruhi hasil-hasil dari sebuah kontrak. Jadi dapat disimpulkan bahwa, manajemen laba adalah tindakan manajer atau perusahaan dalam merubah item-item dalam laporan keuangan menggunakan kebijakan akuntansi untuk mempengaruhi laba perusahaan.

\section{Motivasi Manajemen Laba}

Zimmerman (1986) perilaku manajemen laba dapat disebabkan oleh tiga hipotesa yaitu hipotesis rencana bonus, hipotesis kontrak utang jangka panjang dan hipotesis biaya politik.

Hipotesis rencana bonus terjadi pada perusahaan yang memiliki rencana pemberian bonus akan menyebabkan manajer perusahaan akan lebih memilih metode akuntansi yang dapat menggeser laba dari masa depan ke masa kini sehingga dapat menaikkan laba saat ini. Hipotesis kontrak utang jangka panjang (hipotesis debt to equity), perusahaan yang mempunyai rasio debt to equity tinggi menyebabkan manajer perusahaan cenderung menggunakan metode akuntansi yang dapat meningkatkan pendapatan atau laba. Hipotesis biaya politik (hipotesis ukuran), perusahaan besar yang memiliki biaya politik tinggi akan menyebabkan manajer akan lebih memilih metode akuntansi yang menangguhkan laba yang dilaporkan dari periode sekarang ke periode masa mendatang sehingga dapat memperkecil laba yang dilaporkan.
Ada berbagai macam alasan mengapa manajer melakukan manajemen laba, Scott (1997) membagi motivasi manajer melakukan manajemen laba sebagai berikut:

1. Rencana bonus (bonus scheme). Dalam usaha untuk mencoba menjelaskan dan memprediksikan pemilihan manajermanajer terhadap kebijakan-kebijakan akuntansi, secara lebih spesifikini merupakan perluasan hipotesis rencana bonus yang menyatakan bahwa para manajer perusahaan yang menggunakan rencana bonus akan memaksimalisasikan pendapatan masa kini atau tahun berjalan mereka;

2. Kontrakutang jangka panjang (debt covenant). Motivasi ini sejalan dengan hipotesis kontrak utang jangka panjang dalam teori akuntansi positif yaitu semakin dekat suatu perusahaan ke pelanggaran perjanjian utang maka manajer akan cenderung memilih metode akuntansi yang dapat memindahkan laba periode mendatang ke periode berjalan sehingga dapat mengurangi kemungkinan perusahaan mengalami pelanggaran kontrak.

3. Motivasi politik (political motivation). Perusahaan-perusahaan besar dan industri strategis cenderung menurunkan laba untuk mengurangi visibilitasnya, khususnya selama periode kemakmuran tinggi. Tindakan ini dilakukan untuk memperoleh kemudahan dan fasilitas dari pemerintah, misalnya subsidi;

4. Motivasi perpajakan (taxation Motivation). Perpajakan merupakan salah satu alasan utama mengapa perusahaan mengurangi laba yang dilaporkan. Dengan mengurangi laba 
yang dilaporkan maka dapat meminimalkan besar pajak yang harus dibayarkan kepada pemerintah;

5. Pergantian Chief Executive Officer (CEO). CEO yang akan habis masa penugasannya atau pensiun akan melakukan strategi memaksimalkan laba untuk meningkatkan bonusnya. Demikian pula dengan CEO yang kinerjanya kurang baik, ia akan cenderung memaksimalkan laba untuk mencegah atau membatalkan pemecatannya;

6. Penawaran saham perdana (initial public offering). Saat perusahaan go public, informasi keuangan yang ada dalam prospektus merupakan sumber informasi yang penting. Informasi ini dapat dipakai sebagai sinyal kepada calon investor tentang nilai perusahaan. Untuk mempengaruhi keputusan calon investor maka manajer berusaha menaikkan laba yang dilaporkan.

Scott (1997) mengemukakan bentuk-bentuk manajemen laba yang biasanya dilakukan oleh manajer perusahaan, yaitu :

1. Taking a bath, yaitu dilakukan ketika keadaan buruk yang tidak menguntungkan dapat dihindari pada periode berjalan, dengan mengakui biaya-biaya pada waktu yang akan datang dan kerugian periode berjalan. Bentuk manajemen laba ini terjadi pada saat adanya peristiwa yang jarang terjadi seperti perubahan manajemen, merger atau restrukturisasi sehingga perusahaan terpaksa harus melaporkan kerugian seperti pada awal periode pergantian manajemen, maka dalam periode tersebut dengan secara ekstrim pengakuan laba diturunkan dan biaya dinaikkan;

2. Income Minimazion, dilakukan saat perusahaan memperoleh profitabilitas yang tinggi dengan tujuan agar tidak mendapat perhatian secara politis. Kebijakan yang diambil bisa berupa pembebanan iklan, riset dan pengembangan yang cepat dan sebagainya. Cara ini hampir sama dengan taking a bath namun prakteknya kurang ekstrim;

3. Income maximazion, manajer memaksimalkan laba agar memperoleh bonus yang lebih besar. Demikian juga dengan perusahaan yang mendekati suatu pelanggaran kontrak utang jangka panjang, manajer perusahaan tersebut akan cenderung untuk memaksimalkan laba;

4. Income smoothing, merupakan manajemen laba yang paling sering dilakukan dan paling populer. Melalui income smoothing manajer menaikkan atau menurunkan laba untuk mengurangi fluktuasi laba yang dilaporkan sehingga perusahaan terlihat stabil dan tidak berisiko tinggi. Dengan melakukan perataan laba perusahaan dapat mengurangi reaksi pasar yang terlalu besar pada saat perusahaan mengumumkan informasi laba karena dengan variabilitas yang kecil pada laba yang diumumkan, pelaku pasar dapat melakukan prediksi laba perusahaan yang akan datang dengan lebih baik. Perataan laba tidak hanya dapat dilakukan dengan cara akrual diskresioner tetapi juga dapat dilakukan dengan financial derivatif yang dapat meratakan arus kas perusahaan. 


\section{Corporate Social Responsibility (CSR)}

Teori stakeholder menyebutkan bahwa perusahaan bukan entitas yang beroperasi untuk kepentingannya sendiri namun harus juga memberikan manfaat bagi stakeholdernya (Ghozali dan Chariri, 2007). Stakeholder adalah pihak-pihak yang dapat mempengaruhi maupun dipengaruhi perusahaan. Hadi (2014) menjelaskan terjadi pergeseran paradigma perusahaan, yang selama ini lebih ke shareholder atau pemilik menjadi ke arah stakeholdernya, di mana perusahaan yang lebih berfokus pada kepentingan shareholder saja namun juga pada kepentingan stakeholder. CSR adalah salah satu bentuk kegiatan perusahaan untuk menjalin hubungan dengan stakeholder (Hadi 2014). Hal ini dikarenakan, ada kontrak sosial yang terjadi antara perusahaan dengan masyarakat secara luas. Perusahaan menggunakan sumber-sumber daya yang berada di masyarakat. Stakeholder memiliki kemampuan untuk mempengaruhi pemakaian sumber-sumber daya tersebut (Ghozali dan Chariri, 2007).

World Business Council for Sustainabale Development (WBCSD) mendefinisikan CSR sebagai komitmen berkelanjutan oleh dunia usaha untuk memberikan kontribusi kepada pengembangan secara sosial maupun ekonomi untuk komunitas setempat ataupun masyarakat luas. Hadi (2014) mendefinisikan CSR sebagai tindakan perusahaan dengan pertimbangan etis yang diarahkan untuk pengembangan kualitas masyarakat secara luas. Urip (2010) beranggapan CSR secara luas dinilai sebagai ikatan tanggung jawab yang layak dijalankan untuk mencapai manfaat berkelanjutan. UU. No. 40 tahun 2007 menegaskan tanggung jawab sosial dan lingkungan merupakan komitmen perusahaan untuk berperan serta dalam pembangunan ekonomi berkelanjutan guna meningkatkan kualitas dan lingkungan yang bermanfaat.

Dari definisi-definisi tersebut dapat disimpulkan CSR merupakan strategi perusahaan yang mengakomodasi kebutuhan dan kepentingan stakeholder-nya untuk tujuan pertumbuhan berkelanjutan, selain itu perusahaan mempunyai fokus tidak hanya pada manfaat bagi diri sendiri, namun ikut ambil berperan dalam proses pertumbuhan masyarakat dan lingkungan. Dalam konsep triple bottom line yang dikembangkan John Elkington (Urip 2010), dikenal konsep 3P yaitu profit, people dan planet, profit yaitu, tujuan perusahaan untuk mencapai keberlanjutan ekonomi, people yaitu menjamin kemakmuran masyarakat, dan planet menjamin lingkungan yang kondusif. Ketiganya harus berjalan secara sinergis dan berkesinambungan agar tercipta iklim perusahaan yang baik sehingga eksistensi perusahaan juga terjamin dengan citra atau reputasi positif yang didapatkan dari legitimasi masyarakat (Urip 2010).

Hackston et.al (1996) mengemukakan bahwa pengungkapan CSR terdiri dari 7 tema yaitu lingkungan, energi, kesehatan dan keselamatan tenaga kerja, tenaga kerja, produk, keterlibatan masyarakat, dan umum. Ketujuh tema tersebut dijabarkan dalam 78 item pengungkapan yang telah disesuaikan dengan peraturan yang berlaku dan kondisi yang ada di Indonesia, yaitu : 
1. Lingkungan.

Pengendalian polusi, pencegahan atau perbaikan kerusakan lingkungan, konservasi sumber alam, menerima penghargaan yang berkaitan dengan program lingkungan pengolahan limbah, dan mempelajari dampak lingkungan;

2. Energi.

Menggunakan energi lebih efisien, memanfaatkan barang bekas, membahas upaya perusahaan dalam mengurangi konsumsi energi, pengungkapan peningkatan dan efisiensi energi produk, riset yang mengarah pada peningkatan efisiensi energi produk, riset yang mengarah pada peningkatan efisiensi, dan mengungkapkan kebijakan energi perusahaan;

3. Kesehatan dan keselamatan tenaga kerja.

Mengurangi polusi, iritasi atau resiko dalam lingkungan kerja, mempromosikan keselamatan tenaga kerja dan kesehatan fisik atau mental, mengungkapkan statistik kecelakaan kerja, menaati peraturan standar kesehatan dan keselamatan kerja, menetapkan suatu komite keselamatan kerja;

4. Lain-lain tenaga kerja.

Pelatihan tenaga kerja melalui program tertentu di tempat kerja, mendirikan suatu pusat pelatihan tenaga kerja, mengungkapan persentase gaji untuk pensiun, mengungkapkan kebijakan penggajian dalam perusahaan, mengungkapkan jumlah tenaga kerja dalam perusahaan, mengungkapkan tingkat manajerial yang ada, mengungkapkan jumlah staf, masa kerja dan kelompok usia;
5. Produk.

Pengungkapan informasi pengembangan produk perusahaan, pengungkapan informasi proyek riset, membuat produk lebih aman untuk konsumen, melaksanakan riset atas tingkat keselamatan produk perusahaan, pengungkapan peningkatan kebersihan/ kesehatan dalam pengolahan dan penyiapan produk, pengungkapan informasi atas keselamatan produk perusahaan;

6. Keterlibatan masyarakat.

Sumbangan tunai dan produk, pelayanan untuk mendukung aktivitas masyarakat, pendidikan dan seni, tenaga kerja paruh waktu, sebagai sponsor untuk proyek kesehatan masyarakat, sebagai sponsor konferensi pendidikan, membiayai program beasiswa, membuka fasilitas perusahaan untuk masyarakat;

7. Umum.

Pengungkapan tujuan kebijakan perusahaan secara umum yang berkaitan dengan kegiatan CSR kepada masyarakat dan informasi yang berhubungan dengan tanggungjawab sosial perusahaan selain yang telah disebutkan di atas;

\section{Motivasi Kegiatan Corporate Social Responsibility (CSR)}

Ambadar (2008) mengemukakan beberapa motivasi dan manfaat yang diharapkan perusahaan dengan melakukan CSR meliputi : a) perusahaan terhindar dari reputasi negatif perusak lingkungan yang hanya mengejar keuntungan jangka pendek tanpa memperdulikan akibat dari perilaku buruk perusahaan; b) 
kerangka kerja etis yang kokoh dapat membantu para manajer dan karyawan menghadapi masalah seperti permintaan lapangan kerja di lingkungan di mana perusahaan bekerja; c) perusahaan mendapat rasa hormat dari kelompok inti masyarakat yang membutuhkan keberadaan perusahaan khususnya dalam hal penyediaan lapangan pekerjaan; d) perilaku etis perusahaan aman dari gangguan lingkungan sekitar sehingga dapat beroperasi secara lancar.

Selanjutnya dalam ISO 26000 disebutkan bahwa motivasi perusahaan untuk melakukan aktivitas CSR adalah :

1. Mendorong lebih banyak informasi dalam pengambilan keputusan berdasarkan peningkatan pemahaman terhadap ekspektasi masyarakat, peluang jika kita melakukan tanggung jawab sosial (termasuk manajemen risiko hukum yang lebih baik) dan risiko jika tidak bertanggung jawab secara sosial;

2. Meningkatkan praktik pengelolaan risiko dari organisasi;

3. Meningkatkan reputasi organisasi dan menumbuhkan kepercayaan publik yang lebih besar;

4. Meningkatkan daya saing organisasi;

5. Meningkatkan hubungan organisasi dengan para stakeholder dan kapasitasnya untuk inovasi melalui paparan perspektif baru dan kontak dengan para stakeholder;

6. Meningkatkan loyalitas dan semangat kerja karyawan, meningkatkan keselamatan dan kesehatan karyawan yang berdampak positif pada kemampuan organisasi untuk merekrut, memotivasi, dan mempertahankan karyawan;
7. Memperoleh penghematan terkait dengan peningkatan produktivitas dan efisiensi sumber dana, konsumsi air dan energi yang lebih rendah, mengurangi limbah, dan meningkatkan ketersediaan bahan baku;

8. Meningkatkan keandalan dan keadilan transaksi melalui keterlibatan politik yang bertanggungjawab, persaingan yang adil dan tidak adanya korupsi;

9. Mencegah atau mengurangi potensi konflik dengan konsumen tentang produk atau jasa;

10. Memberikankontribusipadakelangsunganjangka panjang organisasi dengan mempromosikan keberlanjutan sumber daya alam dan jasa lingkungan;

11. Kontribusi kepada masyarakat dan untuk memperkuat masyarakat umum dan lembaga.

\section{Corporate Social Responsibility (CSR) Meminimalkan Manajemen Laba}

Menurut Healy dan Wahlen (1999) manajemen laba terjadi ketika para manajer menggunakan keputusan tertentu dalam laporan keuangan dan mengubah transaksi untuk mengubah laporan keuangan sehingga menyesatkan stakeholder yang ingin mengetahui kinerja ekonomi yang diperoleh perusahaan atau untuk mempengaruhi hasil kontrak yang menggunakan angka-angka akuntansi yang dilaporkan dalam laporan keuangan. Dalam hubungan antara prinsipal dan agen terdapat suatu konflik kepentingan akibat dari tujuan yang berbeda antara kedua pihak. Pihak prinsipal perusahaan tidak memiliki informasi yang cukup mengenai keadaan perusahaan dan kinerja manajer sedangkan agent memiliki 
informasi yang lebih banyak terkait dengan kondisi perusahaan. Lebih lanjut lagi dengan didorong adanya kepentingan yang berbeda maka manajer dapat memanfaatkan keadaan tersebut untuk melakukan manajemen laba terhadap laporan keuangan perusahaan sehingga tidak menunjukkan keadaan yang sesungguhnya. Akibatnya pemilik perusahaan tidak dapat melakukan pengambilan keputusan investasi secara optimal.

Pada saat pemilik perusahaan menemukan adanya indikasi terjadi manajemen laba di dalam perusahaannya maka nilai perusahaan langsung turun drastis pada pasar modal. Akibatnya kejadian ini akan berdampak terhadap pemilik perusahaan dan stakeholder yang lainnya. Usaha yang memungkinkan dilakukan oleh manajer untuk mengamankan posisi mereka adalah dengan membuat dan melibatkan diri dalam kegiatan yang bertujuan untuk meningkatkan hubungan antara perusahaan dengan stakeholder dan lingkungan masyarakat, dalam hal ini CSR. Untuk menarik dukungan dari kelompok tersebut kegiatan CSR yang bisa dilakukan adalah dengan memasukkan aspek sosial ke dalam proses produksi, mengadopsi program pengembangan sumber daya manusia secara progresif meningkatkan kegiatan yang ramah lingkungan melalui kegiatan daur ulang dan pengurangan polusi dan limbah atau dengan mempercepat tujuan dari organisasi masyarakat (Mc.Williams, et.al., 2006).

CSR merupakan tanggung jawab perusahaan terhadap masyarakat. Perusahaan yang berkontribusi terhadap CSR tidak hanya berfokus pada profit, namun juga ikut andil dalam pengembangan kesejahteraan masyarakat. Menurut Chih et.al (2008) perusahaan yang secara sosial bertanggung jawab tidak akan menyembunyikan realisasi pendapatan yang tidak diinginkan, dan karenanya tidak akan melakukan manajemen laba. Caroll (1979) juga menyatakan bahwa CSR adalah tanggung jawab etis perusahaan, sehingga dalam kewajiban moral perusahaan diduga membatasi praktik manajemen laba dan membuat kebijakan yang bertanggung jawab.

Penelitian Scholten dan Kang (2012) menunjukkan hubungan negatif antara CSR terhadap manajemen laba, dan menemukan perusahaan dengan tingkat CSR yang relatif baik secara signifikan berhubungan negatif terhadap manajemen laba. Chih et. al (2008) menemukan hasil serupa dan mengatakan CSR dapat meningkatkan transparansi dan mengurangi kesempatan manajemen dalam melakukan manajemen laba. Kim et.al (2011) meneliti kemungkinan perusahaan yang berkontribusi terhadap CSR dan menemukan praktik manajemen laba melalui akrual diskresioner cenderung rendah dan berkesimpulan sama.

Berdasarkan kajian secara teori dan studi empiris dapat diketahui bahwa semakin tinggi perusahaan dalam menerapkan kegiatan CSR, maka akan dapat mengurangi terjadinya praktik manajemen laba yang akan dilakukan oleh pihak manajemen perusahaan. Karena laporan keuangan yang dibuat oleh pihak manajemen dan dibaca oleh banyak stakeholder, maka manajemen dituntut untuk menyusun laporan keuangan secara jujur dan akuntabel. Kegiatan CSR perusahaan melibatkan banyak stakeholder, 
kegiatan CSR dalam hal ini berperan sebagai alat kontrol untuk pihak manajemen agar tidak melakukan tindakan manajemen laba yang dapat merugikan pihak stakeholder.

\section{PENUTUP}

Manajemen laba adalah proses campur tangan pihak manajemen dalam pelaporan keuangan eksternal dengan tujuan untuk menguntungkan diri sendiri. Manajemen laba merupakan salah satu faktor yang dapat mengurangi kredibilitas laporan keuangan, dapat menambah bias dalam laporan keuangan dan dapat mengganggu pemakai laporan keuangan. Umumnya alasan pihak manajemen dalam melakukan tindakan manajemen laba adalah untuk meningkatkan kepercayaan pemegang saham terhadap manajer, memperbaiki hubungan dengan pihak kreditor, dan dapat menarik investor untuk menanamkan modalnya terutama pada saat perusahaan ingin melaksanakan IPO (Initial Public Offering).

Manajemen laba dapat diterapkan dalam penyusunan laporan keuangan melalui creative accounting practices yaitu pemilihan metoda akuntansi, klasifikasi sistem akuntansi dan pengaturan waktu transaksi. Pengaturan waktu transaksi dan klasifikasi sistem akuntansi berpengaruh terhadap manajemen laba dalam penyusunan laporan keuangan. Praktik manajemen laba dapat juga dilakukan melalui pemilihan metode akuntansi persediaan, depresiasi aktiva tetap, kapitalisasi pensiun, inflasi, dan amortisasi.

Semakin banyak investor yang tertarik pada saham suatu perusahaan yang telah mendapatkan treatment manajemen laba melalui kegiatan meningkatkan laba maka akan semakin baik kinerja perusahaan. Hal ini sejalan dengan tujuan kegiatan serta pengungkapan CSR. Adapun manfaat dari kegiatan CSR tersebut adalah meningkatkan penjualan dan pangsa pasar, menguatkan posisi merk, meningkatkan reputasi dan citra perusahaan, meningkatkan daya tarik investor dan analisis keuangan. Dengan kegiatan CSR yang dilakukan oleh perusahaan maka akan lebih meyakinkan pihak stakeholder atas laporan keuangan yang dilaporkan oleh pihak manajemen.

\section{DAFTAR KEPUSTAKAAN}

Assih, et.al, 2005, Pengaruh Manajemen Laba Pada Nilai dan Kinerja Perusahaan", Jurnal Akuntansi dan Keuangan Indonesia, Vol. 2 No. 2 pp.125-144

Ambadar, J. 2008. CSR dalam Praktik di Indonesia. PT Elex Media Komputindo : Jakarta

Brammer, S. and Pavelin, S. (2006) “Corporate Reputation and Social Performance: The Importance of Fit" Journal of Management Studies, 43(3), 435-455.

Castelo. and Rodrigues, Lu'cia Lima. 2008. Factors Influencing Social Responsibility Disclosure by Portuguese Companies, Journal of Business Ethics, 83, 685-701.

Chih, et al, 2008. The Relationship Between Corporate Social Responsibility and Earnings Management: An Exploratory Study, Volume 104, Issue 4, pp 461-471 
JURNAL IMARA

Carrol, J. W, 1979. Religion In American 1950 To The Present, New York: Herper \& Room

Charles W.Mulford, Eugene E.Comiskey. 2002. The Financial Numbers Game. Cambridge : Jhon Wiley \& Sons Inc.

Dechow, Patricia M. 1994, “Accounting Earnings and Cash Flows As Measures of Firm performance: The Role of Accounting Accruals". Journal of Accounting and Economics. No. 18 P. Pp 3-42

Erica. Et.al. 2011. Corporate Social Responsibility Reporting and Earnings Management: The Role of Political Costs. Australian Accounting Business and Journal. Vol 5.

Fombrun, C. J., Gardberg, N. A., Sever, J. M. (2000). The Reputation Quotient ${ }^{S M}$ : A multistakeholder measure of corporate reputation. The Journal of Brand management, 7(4): 241-255.

Gumanti, T.A. 2000. Earning Management Dalam Penawaran Pasar Perdana Di Bursa Efek Jakarta. Simposium Nasional Akuntansi III., Jakarta.

Ghozali dan Chariri, 2007. Teori Akuntansi. Semarang: Badan Penerbit Undip.

Healy, P.M., and Wahlen, J M. 1999. A Review of The Earnings Management Literature and Its Implications for Standard Setting. Accounting Horizons, Vol. 13 No. 4, pp. 365-383

Hadi, Nur. (2011). Corporate Social Responsibility edisi Pertama. Yogyakarta : Graha Ilmu.
Hackston, David and Markus J. Milne, 1996. “Some Determinants of Social and Environmental Disclosure in New Zealand Companies", Accounting, Auditing and Accountability Journal.

Jensen, M. C., \& Meckling, W. H. 1976. Theory of the Firm: Managerial Behavior, Agency Costs and Ownership Structure. Journal of Financial Economics Vol. 3, No. 4 , p.305-360.

McWilliams, A., Siegel, D.S. and Wright, P.M. (2006) Corporate Social Responsibility: Strategic Implications, Journal of Management Studies, 43, 1-18.

Prior, D.J.S, 2008, Are socially responsible managers really ethical? Exploring the relationship betwen earnings management and corporate social responsibility, Corporate governance: An International Review 16(3):443-459

Schipper, K. 1989, Commentary on Earnings Management"

Scott,2003, Financial Accounting Theory (Third ed.), Pearson Education Canada Inc.

Scott, William R. 1997. Financial Accounting Theory, 2nd Edition, Canada Inc.,Prentices Hall

Urip, S. 2010. CSR Strategies: For a Competitive Edge in Emerging Markets. Singapore: John Wiley \& Sons (Asia).

Watts, R, L., and Zimmerman, J, L. 1986, Positive Accounting Theory. New York, Prentice Hall. 